\title{
CONTRIBUIÇÕES DAS FUNÇÕES EXECUTIVAS E REGULAÇÃO EMOCIONAL PARA A EDUCAÇÃO
}

\section{ARTIGO ORIGINAL}

FERNANDES, Márcio Adriane ${ }^{1}$

FERNANDES, Márcio Adriane. Contribuições das funções executivas e regulação emocional para a educação. Revista Científica Multidisciplinar Núcleo do Conhecimento. Ano 06, Ed. 07, Vol. 10, pp. 137-164. Julho de 2021. ISSN: 24480959, Link de acesso:

https://www.nucleodoconhecimento.com.br/educacao/regulacao-emocional, $\quad$ DOI; 10.32749/nucleodoconhecimento.com.br/educacao/regulacao-emocional

\section{RESUMO}

Diretrizes sugeridas no documento da Base Nacional Comum Curricular (BNCC) indicam a necessidade de uma formação global, ou seja, uma formação cognitiva e emocional do aluno. Duas habilidades indispensáveis para a formação nestes dois domínios são as funções executivas e a regulação emocional. O presente trabalho tem como objetivo fazer uma revisão da literatura científica sobre a importância das funções executivas e da regulação emocional na formação holística de alunos do ensino fundamental. Esta pesquisa oferece subsídios às Escolas para que cumpram as exigências legais do Ministério da Educação e Cultura (MEC) que se fará legislar a partir ano de 2020. Após uma rápida explanação das bases biológicas algumas técnicas de avaliações serão apresentadas como exemplo de como as funções executivas e a regulação emocional podem contribuir na aprendizagem demonstrando, assim, que há intervenções práticas de como melhorar o desempenho acadêmico via instrumentalização da neurociência.

\footnotetext{
${ }^{1}$ Especialização em Neurociência.

RC: 92018

Disponível em: https://www.nucleodoconhecimento.com.br/educacao/regulacaoemocional
} 
Palavras-chave: Função Executiva, Regulação Emocional, Educação, Ensino.

\section{INTRODUÇÃO}

As diretrizes instituídas pelo Ministério da Educação e Cultura (MEC) devem ser efetivadas a partir do ano de 2020 conforme a lei oㅜ 13.415/2017. Para tal haverá, na Base Nacional Comum Curricular (BNCC), orientações para uma nova elaboração dos currículos nas escolas das redes públicas e privadas em todo território nacional (BNCC, 2017, p. 5). Os alunos deverão cumprir 1.000 horas anuais obrigatórias e 800 horas que serão destinadas aos itinerários formativos, onde serão oferecidos aos alunos a opção de vários segmentos: projetos, disciplinas não obrigatórias além de cursos técnicos e profissionais (BNCC, 2017, p. 470 e 475).

Deste modo, as escolas deverão oferecer aos estudantes, por exemplo, o que o MEC chama de "Projeto de Vida" (6 $6^{a}$ competência da BNCC, 2017, p. 472): uma ferramenta para desenvolver nos estudantes certa autonomia possibilitando a capacidade de fazerem escolhas conscientes e responsáveis com descobertas das aspirações e atributos individuais, simultaneamente.

Diante do quadro que se apresenta - formação cognitiva e socioemocional do aluno essa pesquisa tem como objetivo investigar, por meio de revisão da literatura, a importância das funções executivas (FE) e da regulação emocional (RE) no auxílio do desempenho escolar cognitivo e do desenvolvimento socioemocional dos alunos. Ou seja, esse trabalho visa propor como a neurociência pode fornecer subsídios para o cumprimento das exigências da nova educação brasileira. Sem delongas, há diretrizes no documento da BNCC que indicam uma formação "global", ou seja, uma formação cognitiva e emocional do aluno.

Nesse contexto, a Base Nacional Comum Curricular (BNCC) afirma, de maneira explícita, o seu compromisso com a educação integral. Reconhece, assim, que a Educação Básica deve visar à formação e ao desenvolvimento humano global, o que implica compreender a complexidade e a não linearidade desse desenvolvimento, rompendo com visões reducionistas que

RC: 92018

Disponível em: https://www.nucleodoconhecimento.com.br/educacao/regulacaoemocional 
privilegiam ou a dimensão intelectual (cognitiva) ou a dimensão afetiva. (BNCC, 2017, p. 13)

De acordo com Cardoso (2017), as FE e suas competências, tais como controle inibitório, memória de trabalho, flexibilidade cognitiva, inteligência fluida, a capacidade para planejar e encontrar soluções, autorregulação e metacognição juntamente com a RE são indispensáveis para um excelente desempenho na aprendizagem. Assim, cabe aqui definir e conceituar tais propostas que visam dar suporte às demandas educacionais.

Dentro das categorizações da Diamond (2013) essas três partes citadas acima das Funções executivas são as denominadas básicas. Há outras competências denominadas de "complexas", que são: Inteligência Fluida, Planejamento, autorregulação e metacognição (DIAMOND, 2013).

O filósofo David Hume tratou desse assunto pela via da filosofia experimental no seu livro "Tratado da Natureza Humana" onde descreve a capacidade que temos de, através das impressões, produzir, a partir de ideias simples, ideias complexas. Através das ligações de ideias simples registradas em nossa memória pelas impressões sensoriais vamos formando novas ideias (HUME, 1999). Tais "Ideias Complexas" são chamadas por Diamond (2013) de "Inteligência Fluida", a capacidade de fazer ligações e relacionar temas diferentes na tentativa de resolver problemas. É o tipo de inteligência que independe de práticas específicas anteriores. Utiliza-se de conteúdos de memória para abstrair outras ideias.

O que Diamond (2013) chamou de "planejamento" foi a capacidade de elaborar e executar planos, ou seja, medir todas as situações antes de iniciar um projeto e traçar meios e caminhos para atingir determinada meta.

Ainda a "autorregulação". Uma possível definição: "autorregulação como a habilidade de monitorar e modular a emoção, a cognição e o comportamento, para atingir um objetivo e/ou adaptar às demandas cognitivas e sociais para situações específicas" (LINHARES, 2015). A autorregulação é constituída de alguns

RC: 92018

Disponível em: https://www.nucleodoconhecimento.com.br/educacao/regulacaoemocional 
componentes que, na composição desse trabalho, será avaliado a possibilidade de apresentá-los e aplicá-los.

Por fim, a metacognição, a capacidade de compreender quando a própria mente está interagindo com o meio, monitorando-o e fazendo uma autorregulação em si mesma. De acordo com Jou (2010) a metacognição é uma etapa do processamento cognitivo em escala mais elevada pelo conhecimento adquirido e armazenado. Jou sugere que a metacognição se dá num processo evolutivo por causa da necessidade de adaptação.

Outro tema abordado será sobre a regulação emocional (RE) como excelente instrumento de auxílio para um bom aprendizado. No decorrer desse projeto será realizada uma pesquisa sobre a aproximação da $R E$ como subcategoria das funções executivas (autorregulação), o que Diamond (2013) chamou de "competência complexa" das FE. Ou, que a RE funcione como um instrumento modificador da experiência emocional para promoção do bem-estar pessoal (REIS, 2018) independente da FE (Reis menciona a RE sem citar, em nenhum momento, as FE). Essa pesquisa será necessária, visto que, em algum momento a RE se apresenta como "autorregulação", um subproduto das funções executivas (CRUVINEL, 2010; HOFMANN, 2012) e, num outro momento, a RE se apresenta como categoria separada das FE.

Parte do trabalho tratará de definir os termos para que, assim, tenhamos uma unidade linguística e de compreensão unitária tornando, assim, esse projeto dialogável com qualquer instância e com qualquer campo de saberes. Por hora, no caso das FE optar-se-á pela definição que mostra as FE como um conjunto de fatores neurológicos que contribuem para que o indivíduo alcance objetivos pretendidos. Esse conjunto de fatores damos o nome de "competências" citadas acima. No caso da RE, a opção será tratá-la como um processo modificador de experiências emocionais que promovam o bem-estar.

RC: 92018

Disponível em: https://www.nucleodoconhecimento.com.br/educacao/regulacaoemocional 
Finalmente mencionaremos alguns pontos sobre as verificações técnicas empíricas. Alguns instrumentos de avaliação cognitiva e emocional já estão sendo usados com propriedade como, por exemplo:

- Teste AC (Teste de Atenção Controlada).

- Escala de Avaliação das Estratégias de Aprendizagem para o Ensino Fundamental (EAVAP-EF). (SUEHIRO, 2018).

- Escala de Avaliação da Regulação Emocional para Estudantes do Ensino Fundamental (ERE-EF). (lbid)

Importante lembrar que a pesquisa que está sendo feita visa contribuições da neurociência para melhorar as condições de alunos do Ensino Médio. Isso implica num público-alvo predominantemente adolescente. Assim, a concentração desse trabalho ficará restrita a essa parte da população e todas as referências serão canalizadas para atender essa faixa etária.

\section{FUNÇÕES EXECUTIVAS}

Alguns teóricos consideram as $\mathrm{FE}$ como um processo que envolve um único elemento (ETTENHOFER; HOMBRICK; ABELES, 2006). As subdivisões é um mero aparato didático. Garcia-Andres (2010) está entre os que entendem que a FE é um processo multidimensional e contém sub-habilidades tais como: deslocamento, memória de trabalho, inibição, flexibilidade e planejamento.

Goldstein (2014) realizou uma revisão das definições de funções executivas e nos apresentou uma coleção destas ao longo da história (1966-2011) propostas por vários psicólogos e neurocientistas. O que Friedman (2007) e Diamond (2013) chamaram de "família de processos cognitivos" modulando o pensamento, Chan (2008) denominou as FE de "guarda-chuva": um processo genérico que engloba várias funções cerebrais.

RC: 92018

Disponível em: https://www.nucleodoconhecimento.com.br/educacao/regulacaoemocional 
Pode-se pensar em algumas ações possíveis para das funções executivas diante desse quadro, como por exemplo: pensar antes de agir; diante de situações imprevistas ser capaz de tomar a decisão para o melhor resultado; resistir às tentações e ao imediatismo e; manter o foco.

Diamond (2013) e Cardoso (2017) falam de subdivisões das funções executivas para melhor compreensão didática. Diamond (2013) subdivide as FE em competências básicas:

- Controle Inibitório;

- Memória de Trabalho (que abarca outros subitens):

- Alça fonológica;

- Esboço Visuoespacial;

- Executivo Central;

- Buffer Episódico.

- Flexibilidade Cognitiva.

E competências complexas:

- Inteligência Fluida (raciocínio e resolução de problemas);

- Planejamento.

\subsection{CONTROLE INIBITÓRIO}

Ao mencionar o controle inibitório fala-se da capacidade de favorecer ou não um ou outro comportamento que, em determinada situação, seja inadequado, irrelevante ou, adequado e relevante (CARLSON, 2007). Desenvolver o Controle Inibitório contribui para que jovens possam resistir a certas distrações que lhes tirem o foco e, juntamente, selecionar estímulos que sejam relevantes para a realização de determinado trabalho. Dentro do campo do Controle Inibitório temos a (1) "Inibição de Resposta", ou seja, a resistência ao impulso da primeira resposta (um autocontrole em tomadas de decisões por ações e por falas) e, (2) o "Controle de

RC: 92018

Disponível em: https://www.nucleodoconhecimento.com.br/educacao/regulacaoemocional 
Interferência", que atua na área dos pensamentos e memória ou qualquer outro fator que possa interferir na tentativa de dividir ou desviar a atenção.

\subsection{MEMÓRIA DE TRABALHO}

A segunda competência das funções executivas mencionada é a memória de trabalho (MT), o qual diz respeito à retenção de informações na memória por curto espaço de tempo até que o trabalho seja executado. Para uma pessoa entender qualquer coisa que se desdobra ao longo do tempo exige-se ter em mente as noções dos fatos ocorridos e relacioná-los para uma nova proposta (e.g., fazer cálculos matemáticos de cabeça). Diamond (2013) comenta que a MT é fundamental para a capacidade de formar conexões entre coisas aparentemente não relacionáveis e de separar elementos que aparentemente são conectados, mas que são distintos.

Cardoso (2017) nos informa de quatro componentes fluidos da memória de trabalho:

- Alça fonológica: componente auditivo que tem por ação resgatar e separar as informações auditivas do ambiente;

- Esboço Viso espacial: responsável pelo armazenamento temporário de informações espaciais e visuais;

- Executivo Central: que atua no gerenciamento de informações provindos da alça fonológica e pelo esboço visuoespacial. O executivo central está localizado nas regiões pré-frontais dos lobos frontais;

- Buffer Episódico que coordena as diversas áreas como um depósito temporário das informações (BADDELEY, 2000).

\subsection{FLEXIBILIDADE COGNITIVA}

A terceira competência das funções executivas é a flexibilidade cognitiva (FC). Como o próprio nome diz é a capacidade de flexibilizar focos atencionais considerando o que, e quais as adaptações serão necessárias para novas

RC: 92018

Disponível em: https://www.nucleodoconhecimento.com.br/educacao/regulacaoemocional 
demandas. Guerra (2014) nos apresenta uma ampla pesquisa conceitual sobre essa capacidade de redirecionar o conhecimento. É através da FC que se muda perspectivas espaciais (e.g., é possível imaginar uma situação totalmente possível além da situação atual) e perspectivas interpessoais - tentativa de ver a situação no olhar do outro.

A FC tem por objetivo encontrar soluções para os problemas buscando alternativas diferentes das aplicadas anteriormente. Assim, para encontrar novas respostas, é necessário descartar as tentativas mentais de antes. Uma característica da FC é a de funcionar e contribuir mutuamente com o controle inibitório e com a memória de trabalho.

Guerra (2014) finalmente assume a definição de flexibilidade cognitiva adotando elementos processuais e elementos experienciais. Para a autora a definição adotada coloca a flexibilidade cognitiva em posição superior. O conhecimento é apresentado como "recepcionado, representado, (r)estruturado e aplicado na elaboração de respostas" (2014, p. 9). Ainda, Guerra subdivide a flexibilidade cognitiva em três partes: (1) flexibilidade de atenção; (2) flexibilidade de representação: "a capacidade de desconstrução e reconstrução das informações captadas e ou armazenadas" (2014, p. 9) e, (3) flexibilidade de resposta.

\subsection{INTELIGÊNCIA FLUIDA E PLANEJAMENTO}

Competências denominadas de "complexas" (DIAMOND, 2013), que podem ser traduzidas como "superiores" são:

- Inteligência Fluida (que inclui o raciocínio e resolução de problemas): diferente de uma inteligência fixa, tal inteligência fornece habilidade de raciocínio rápido em novas situações dando conta de resolução de problema num curto espaço de tempo (PRIME, 2002; DIAMOND, 2013). Neste caso, informações guardadas na memória a longo prazo não são utilizadas. Há uma habilidade de adaptar-se a situações de emergências. Envolve capacidade de

RC: 92018

Disponível em: https://www.nucleodoconhecimento.com.br/educacao/regulacaoemocional 
encontrar saídas, mesmo que não se tenha disponível ferramentas (encontrar caminhos seguros sem bússola). Também envolve a capacidade de novos aprendizados e de se fazer raciocínios abstratos.

- Planejamento: Em simples palavras pode-se dizer que planejamento é a capacidade cognitiva de pensar em futuro de curto, médio e de longo prazo. É a capacidade de pensar (processo mental) em rotas para alcançar um determinado objetivo. E, em se tratando de rotas, são todas as possibilidades de caminhos ao longo do percurso para se chegar ao objetivo planejado. No cérebro há vias de novos caminhos e de conexões sinápticas. Esse trabalho, por exemplo, funciona dentro do contexto do planejamento: tomar decisões sobre o que incluir e o que excluir; quais caminhos seguir; quais artigos selecionar e usar; qual o objetivo final e como construir caminhos para se chegar até ele; entre outras coisas.

Outras duas áreas que funcionam a parte das funções executivas, mas que, no entendimento de Diamond (2013), funcionam em parceria indireta, são a autorregulação e a metacognição. Veremos essas áreas na sequência por estarem fora do campo das funções executivas como sugere Diamond (2013).

\section{REGULAÇÃO EMOCIONAL}

Neste trabalho a autorregulação (o controle das emoções) e o controle inibitório (controle cognitivo/comportamental) serão desenvolvidos entrelaçados: as emoções contribuem na organização do pensamento cognitivo e, por outro lado, processos cognitivos contribuem na regulação das emoções como bem mencionou Hofmann (2014). Para esse autor FE e RE podem ser vinculados com base em quatro proposições: (1) Três das habilidades encontradas nas FE coincidem com mecanismos importantes nas atividades de autorregulação; (2) a habilidade, memória de trabalho, vista como uma faceta cognitiva pode ser vista, também, na regulação das emoções; (3) quando há algum tipo de falha processual em um,

RC: 92018

Disponível em: https://www.nucleodoconhecimento.com.br/educacao/regulacaoemocional 
significa, em vários fatores, falha no outro e; (4) quando as FE são treinadas, as RE são beneficiadas (HOFMANN, 2014).

$\mathrm{Na}$ mesma perspectiva temos Crum (2017) afirmando que as emoções são reguladas com a ajuda das funções executivas na maioria das vezes (o cérebro controla certos aspectos no processamento das informações). Pode-se verificar essa tendência em Diamond, onde a regulação emocional “... se justapõe substancialmente ao controle inibitório..." (2013, p. 152). Por essas palavras Diamond diz que há, sim, uma diferença entre a $\mathrm{RE}$ e $\circ \mathrm{Cl}$ no que concerne a proposta pedagógica, mas que, uma se coloca no lugar da outra a todo tempo. Mas o que é a autorregulação (além de se justapor ao controle inibitório)?

Garcia-Andres (2010) adotará o entendimento de que a RE é parte integrante da autorregulação e que o estudo combinado entre funções executivas e regulação emocional são de máxima importância para a interação social e nas relações socioemocionais. O autor é da opinião de que se deve utilizar todos os métodos possíveis para medir a regulação emocional para se chegar a resultados mais precisos. Nunes (2013) é da mesma opinião de que a regulação das emoções é essencial para o funcionamento adaptativo e de sua importância no desenvolvimento psicológico saudável. A aquisição de uma regulação emocional estável promove um bom desenvolvimento da personalidade (NUNES, 2013). Por fim, Nunes (2013) nos fala de duas distinções para a regulação emocional: a autorregulação e a regulação social, onde um está envolvido no outro.

O corpo humano reage intrínseca e extrinsecamente aos estímulos internos e externos. Tais estímulos "provocam" as emoções. A capacidade de dar nova direção, controlar, modular e modificar as emoções para que o indivíduo funcione em equilíbrio está relacionada a regulação emocional (EISENBERG, 2010). Silva (2014) chamou esses estímulos internos e externos de processos intrínsecos e extrínsecos. Como intrínsecos temos, por exemplo, as funções cognitivas, neurológicas e, como extrínsecos temos, por exemplo, a cultura familiar, e em 
especial o pai e a mãe. Antes de mais nada é preciso definir as emoções, ou seja, ter a exata compreensão do que está acontecendo comportamental, experiencial e fisiologicamente. É preciso estar atento para o momento em que a emoção influência positiva ou negativamente outras áreas das funções executivas, como a tomada de decisão, a atenção, a memória de trabalho, as interações sociais, entre outras.

Como mencionado ao fim da introdução, esse trabalho visa o período da adolescência. Este período é marcado por alterações diversas no corpo e nos sentimentos: puberdade, psique, questões socioeconômicas (além da complexidade dos processos regulatórios: sistema hormonal, neurológico e cognitivo) que conduzem a novas experiências de ativação emocional. Tais ativações emocionais podem trazer rápidas mudanças de humor e experimentos de emoções negativas. Todas essas interferências estão presentes num período de intensos estressores: relações sociais, finalização do ensino médio e exigência de uma escolha de formação, a expectativa da família, de si mesmo, da sociedade e dos pares e a dificuldade de lidar com novas formas de autonomia. Todas essas interferências exigem do adolescente um aprendizado na regulação dos afetos bem maior do que em qualquer outra fase da vida (SILVA, 2014).

Diante do fato exposto acima é de fundamental importância o apoio familiar (principalmente dos pais dos adolescentes). É dentro do contexto familiar saudável que as crianças aprendem a modelar e expressar suas emoções (BARIOLA, 2012).

Por algum tempo pensou-se na regulação da emoção como um esforço para suprimir e colocar a emoção debaixo de regras, ou seja, as emoções devem ser contidas porque a liberalidade das emoções causa danos. No entanto, Suveg (2007) nos dirá que regular a emoção não é só no aspecto da contensão, e, também da excitação, de fazê-la aparecer. Uma regulação excelente é funcional, ou seja, operar a emoção de maneira que ela seja utilitária, o que gerará um "processo integral na competência socioemocional e na saúde mental" (p.359).

RC: 92018

Disponível em: https://www.nucleodoconhecimento.com.br/educacao/regulacaoemocional 
Como já foi visto, existem poucos relatos de felicidade e de emoções positivas em adolescentes. Junto com isso acrescenta-se o aumento da vulnerabilidade em regular as emoções. Todas essas negativas podem conduzir para sinais de depressão. Assim o adolescente entra num círculo doentio sem fim: a não capacidade de gerenciar as emoções podem conduzir a depressão e, uma pessoa deprimida tem dificuldade de gerenciar a depressão (GILBERT, 2012).

Linhares (2015) nos apresenta três componentes no processo de autorregulação. São eles: (1) regulação cognitiva: relacionada com a capacidade de reter e manipular informações mentalmente (memória de trabalho) e na capacidade de negar à tentação de ter que fazer algo (controle inibitório); (2) regulação emocional: relacionada com a capacidade de manejar, modular, inibir e melhorar a ativação emocional, com o objetivo de responder às demandas sociais e; (3) regulação comportamental: fala da capacidade de ter o controle do próprio comportamento, que inclui: obedecer às demandas e direções dos adultos; controlar respostas impulsivas; adiar engajar-se em atividades específicas.

Rocha (2018)[2], após nos falar um pouco da história dos estudos da regulação emocional, define a RE como "gestão bem-sucedida da ativação emocional para o funcionamento cognitivo e social eficaz" (p.12). Na sequência Rocha (2018) comenta que a função da RE é dar nova organização de forma que as emoções sejam controladas e equilibradas para um bom funcionamento do indivíduo de forma adaptativa.

Emoções, de forma geral, podem ser descritas como positivas ou negativas. A autorregulação das emoções é a condição que se usa para definir o uso das emoções e encontrar um equilíbrio. Nesse sentido, tanto emoções negativas quanto emoções positivas podem contribuir no bom equilíbrio mental e físico/biológico. O medo (considerada emoção negativa), em algumas circunstâncias e em certa medida, pode contribuir com o equilíbrio emocional (livrando a pessoa de assumir um alto risco).

RC: 92018

Disponível em: https://www.nucleodoconhecimento.com.br/educacao/regulacaoemocional 
Numa proposta de revisão bibliográfica, Suehiro (2018) comenta de alguns teóricos que falam de certas estratégias para regular os altos níveis de emoções positivas e negativas: "reavaliação cognitiva da emoção, a supressão da expressão da emoção, o culpar a si próprio, o culpar o outro, exercer controle sobre ruminações do pensamento e colocar a situação em perspectiva" (p.91-92).

Finalmente, Baumeister (2018) nos apresentou a ideia de que o autocontrole é como um músculo; exige esforço, pode ser exercitado, se cansa, se desgasta e pode ser treinado (EVANS, 2016). Por exemplo, todas as vezes que resistimos ficar um pouco mais na cama ou de comer para além da necessidade, estamos exercitando o autocontrole. Essa analogia ficou conhecida como esgotamento do ego. Da mesma maneira que ocorre com o esforço físico que economiza energia quando está quase a se exaurir, no esgotamento do ego há uma conservação de energia (BAUMEISTER, 2018).

\section{BASES NEUROBIOLÓGICAS}

Tendo em vista a literatura investigada sobre bases neurobiológicas da FE e RE, este trabalho focara nas pesquisas com base principal nos trabalhos do neuropsicólogo russo Alexander Luria (1902-1977).

Antes, é preciso dizer, com base nas pesquisas Lurianas, que identificar um local específico no cérebro para reger algum tipo de comportamento complexo seria considerado um esforço em vão. Vejam, como exemplo, o comportamento complexo da linguagem. Ela não é processada por uma única parte do cérebro, mas por uma vasta de ramificações neurais: competência comunicativa, os recursos receptivos, as interpretações abstratas e interpretativas e o sistema motor que depende dos sistemas funcionais. Tais sistemas funcionais envolvem todo tronco encefálico (BASTOS, 2013).

Goldstein (2013), fazendo referência a A.R. Luria, diz sobre os cinco estágios do desenvolvimento humano:

RC: 92018

Disponível em: https://www.nucleodoconhecimento.com.br/educacao/regulacaoemocional 
- Primeira Fase que começa nos primeiros anos de vida com o desenvolvimento das estruturas do tronco cerebral.

- Segunda Fase que envolve as áreas sensoriais primárias (visão, audição e tato) e áreas motoras primárias.

- Terceira Fase acontece a partir dos quatro anos de idade. Áreas de associação secundárias do cérebro são ativadas permitindo a criança reconhecer e reproduzir coisas.

- Quarta Fase, a partir dos sete anos de idade, áreas dos lobos parietais são ativados. Nessa fase habilidades complexas podem ser executadas.

- Quinta e última fase, inicia a partir dos oito anos de idade e irá se completar até os vinte e cinco anos. Nessa fase operações que envolvem os lobos frontais e o sulco central é crucial para o desenvolvimento de habilidades mentais complexas, pensamentos abstratos, metacognição.

Figura 1 - Córtex pré-frontal

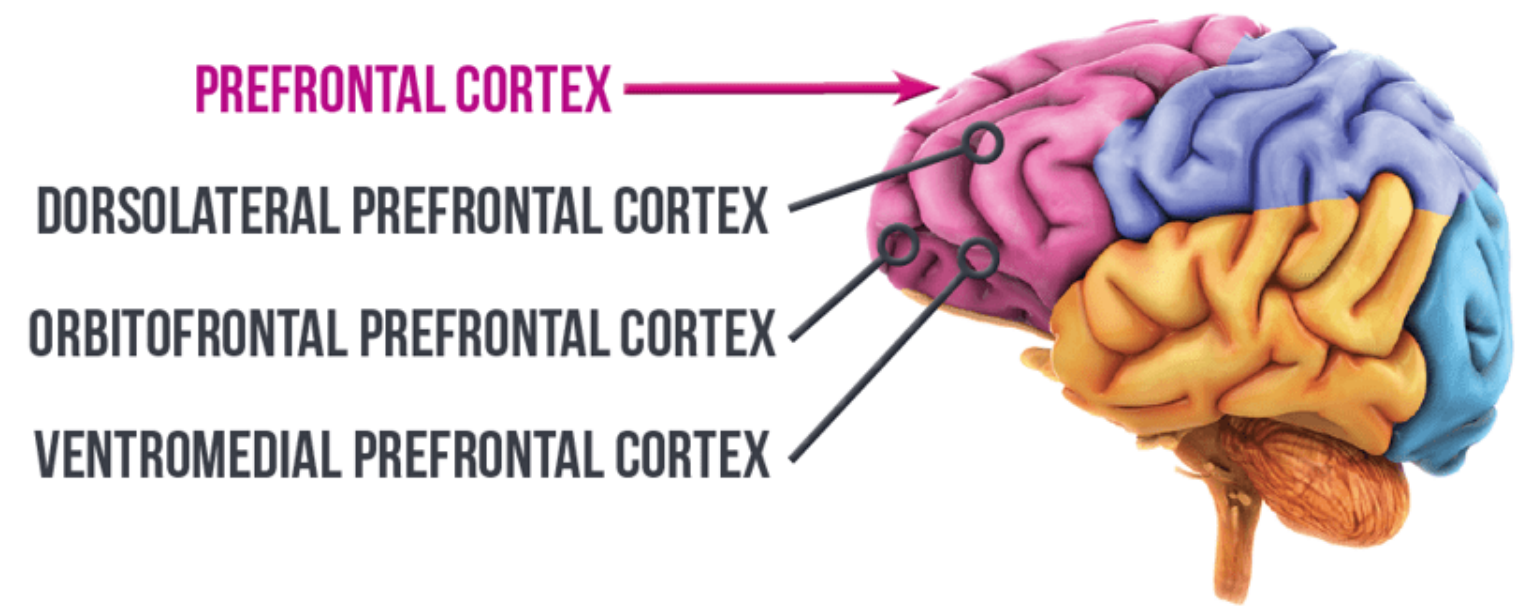

Fonte: https://www.thescienceofpsychotherapy.com/prefrontal-cortex/

O córtex pré-frontal (CPF) é uma área cerebral amplamente conectada, ou seja, recebe informações dos vários córtices sensoriais e, também, da área cognitiva. $O$ CPF se encontra atrás dos olhos e da testa. Dentre todas as partes do cérebro, esta área é a que mais determina a personalidade (SERUCA, 2013), objetivos e valores

RC: 92018

Disponível em: https://www.nucleodoconhecimento.com.br/educacao/regulacaoemocional 
(DAHLITZ, 2017). Ter o CPF em estado saudável é vital para o conhecimento de si mesmo e dos outros. Também de máxima importância para bons relacionamentos e respeito social e, na tomada de decisão. O autor acima avaliou que pessoas que tem o volume do CPF reduzido e as interconexões baixas foram diagnosticadas com transtornos mentais. Esses transtornos mentais podem ser resultados de enfartes frontais bilaterais por vasoespasmo; tumores (malignos e benignos) e ablações cerebrais. O mesmo acontece em pessoas submetidas a estresses repetitivos, encarcerados, sociopatas, pessoas envenenadas por chumbo e usuários contínuos de maconha. Por outro lado, o sentimento de remorso, de culpa, de interpretação correta da realidade indica que o CPF está funcionando adequadamente.

Aquilo que Dahlitz (2017) mencionou sobre transtornos mentais, Damásio (1944) nos alertou sobre esse prejuízo e suas consequências quando trouxe o caso de Phineas Gage que teve o córtex pré-frontal atravessado por uma barra de ferro enquanto trabalhava na construção de uma ferrovia. Tal lesão mudou a personalidade de Gage levando os seus amigos a denominá-lo "não mais Gage".

RC: 92018

Disponível em: https://www.nucleodoconhecimento.com.br/educacao/regulacaoemocional 
Figura 2 - The truth about Phineas Gage

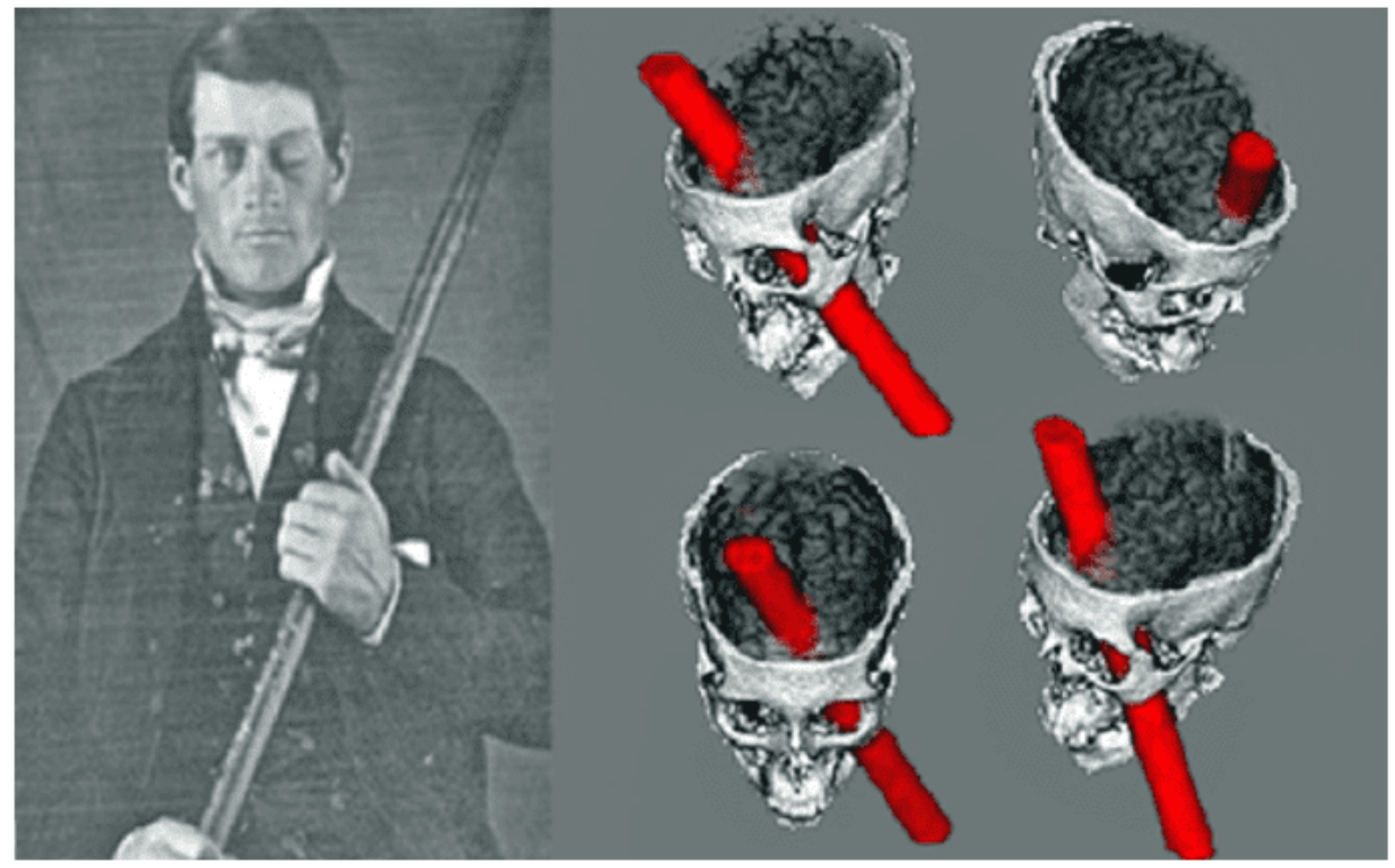

Disponível em: https://peakmemory.me/2015/07/31/the-truth-about-phineas-gage/

Albuquerque (2002), após exames de imagens e testes laboratoriais, chegou à conclusão de que no córtex pré-frontal estão envolvidas as funções executivas (ex.: memória de trabalho, atenção, abstração, planejamento, autorregulação) e as funções comportamentais (ex.: motivação, planejamento, emoções, tomadas de decisões) na tentativa de definir melhor as "síndromes frontais caracterizadas por lesão focal" (p. 125).

Yang (2005) relacionou a ocorrência de comportamentos antissociais com alterações nas estruturas pré-frontais. Tais alterações implicam diretamente num mau funcionamento executivo, em específico nas áreas de organização temporal, planejamento e flexibilidade cognitiva. O mesmo para Diamond (2013), onde as funções executivas estão fortemente associadas ao córtex pré-frontal. É importante lembrar que, para Diamond, essa área tem uma maturação prolongada em 
comparação às outras áreas cerebrais. E, ainda, Almeida (2015) na mesma linha de pensamento, aponta que o córtex pré-frontal regula e implica grandemente no comportamento social. Lesões nas funções relacionadas ao córtex pré-frontal podem produzir maior agressividade, impulsividade e uma desregulação social.

\section{METACOGNIÇÃO E EDUCAÇÃO}

Apesar da metacognição ser parte integrante do conjunto de habilidades que contribuem para um bom desenvolvimento cognitivo, não será dada ênfase neste trabalho pela concentração nos conceitos emocionais que envolvem a autorregulação. Apesar disso, cabe uma definição e aplicação na área da educação.

O que é a mente humana? um compêndio cognitivo que tem capacidade de sentir o meio e interagir com o mesmo. A metacognição é essa capacidade para entender o próprio processo cognitivo; é a capacidade que esse sistema tem de regular e monitorar a si mesmo (JOU, 2006) ou, de voltar para si mesmo para se compreender. Como diz Ribeiro (2003), uma avaliação da própria ação do conhecimento.

A metacognição pode ainda exercer influência sobre a motivação (Jones, 1988), pois o fato de os alunos poderem controlar e gerir os próprios processos cognitivos lhes dão a noção da responsabilidade pelo seu desempenho escolar e gera confiança nas suas próprias capacidades (MORAIS e VALENTE, 1991). Tal procedimento contribui no contexto escolar quando o adolescente procura conhecer o seu próprio método de conhecer, de analisar e avaliar o que e como se conhece.

\section{FUNÇÕES EXECUTIVAS E REGULAÇÃO EMOCIONAL NA EDUCAÇÃO}

As funções executivas juntamente com a regulação emocional são extremamente relevantes no processo de aprendizagem. A questão é: como essas habilidades podem contribuir na educação básica? É imprescindível que tenhamos educadores

RC: 92018

Disponível em: https://www.nucleodoconhecimento.com.br/educacao/regulacaoemocional 
que deem oportunidade e estimulem os alunos a autodescobertas, o que ficou conhecido como "aprendizagem autorregulada" (SUEHIRO; BORUCHOVITCH e SCHELINI, 2018), onde o aluno é co-responsabilizado por sua aprendizagem (FREIRE, 2014). Para tal, é necessário o controle das emoções (RE). Um aluno autorregulado é um aluno que tem um melhor controle sobre suas emoções e consegue enxergar com melhor qualidade os emergentes desafios escolares $e$, encontra meios para lidar com esses desafios.

Uma aprendizagem de qualidade sugere inter-relação em muitos aspectos, como por exemplo, a motivação extrínseca e intrínseca para o aprendizado, controle das emoções, estratégias... Assim sendo, para que o estudante alcance a aprendizagem de qualidade se faz necessário que o mesmo regule a si mesmo e que empregue as estratégias apropriadas nas demandas das tarefas escolares, que gerencie sua autonomia (tempo, importância, qualidade, etc) e que tenha controle sobre suas emoções diante dos desafios escolares emergentes (SUEHIRO et al., 2018).

\subsection{FUNÇÕES EXECUTIVAS E APRENDIZAGEM}

Usar as funções executivas é trabalhoso. Exige esforço para a sua utilização. E, naturalmente somos tendenciosos à lei do menor esforço, o que inclui o sistema nervoso e neuronal (MEDNEWS, 2018). Não somos amigáveis às mudanças preferimos seguir no piloto automático. É mais fácil ceder às tentações do que resistir a elas. Nossos alunos experimentam todos os dias tais confrontos internos entre a comodidade (ficar em casa pela manhã, dar preferência a informações prontas no celular e, até mesmo, reproduzir o que o professor disse em sala de aula) e a criatividade (ter que produzir algo novo com base no que aprendeu, utilizar de sistemas metacognitivos, funcionar o controle inibitório e a memória de trabalho). Ser criativo dá trabalho. No entanto, se eles forem estimulados à criatividade darão muitos frutos.

RC: 92018

Disponível em: https://www.nucleodoconhecimento.com.br/educacao/regulacaoemocional 
Todas as competências das funções executivas são preditivas - apontam para um resultado no futuro (DIAMOND, 2013). Por isso, a melhor fase de se iniciar um trabalho direcionado com as funções executivas é na tenra infância. Crianças orientadas nas FE estão mais propensas a serem mais persistentes na sequência escolar (o que diminuirá a evasão escolar no futuro).

O Controle Inibitório (ou autocontrole), um dos componentes das funções executivas, tem um papel importante e necessário na aprendizagem - funciona como um instrumento controlador: a atenção precisa ser controlada, os pensamentos precisam ser monitorados a todo instante para identificar quais pensamentos que podem contribuir para resolver determinado problema, quais pensamentos que devem permanecer presentes e quais não devem. $O$ aluno deve estar atento ao estímulo principal e ter o controle para ignorar os estímulos que tentam desfocá-lo, o que é chamado de atenção seletiva. Diante de tantos estímulos em sala de aula é necessário ter disciplina para manter-se na tarefa. $O$ aluno deve ter essa autonomia e responsabilidade do seu autocontrole e, também, ser auxiliado pelo professor a completar a tarefa apesar das tentações para desistência.

Para Diamond (2013) a Memória de Trabalho (MT) coopera intimamente com o Controle Inibitório $(\mathrm{Cl})$, e vise versa. Para manter um objetivo em mente se faz uso da $\mathrm{MT}$ e do $\mathrm{Cl}$. Concentrando-se numa determinada informação, outras serão dispensadas. Ao resistir a uma informação específica $(\mathrm{Cl})$ é possível recombinar ideias em volta dessa informação (MT) obtendo, assim melhor desempenho escolar.

Entre muitas opções de distração (frio, calor, conversa paralela, celular, janela, a voz irritante do professor...) a mente do aluno precisa manter o foco $(\mathrm{Cl})$. Caso contrário, esse aluno entra em divagação e terá que repetir o processo pois que, a informação não foi guardada na memória de forma adequada.

O controle inibitório contribui na organização do nosso espaço mental restringindo ou eliminando informações irrelevantes para um determinado processo. $O$ que não for útil em tal processo o $\mathrm{Cl}$ descarta.

RC: 92018

Disponível em: https://www.nucleodoconhecimento.com.br/educacao/regulacaoemocional 


\subsection{REGULAÇÃO EMOCIONAL E APRENDIZAGEM}

Numa avaliação computadorizada através de questionários sobre aprendizado, emoção e motivação autorregulada, Mega (2014) chegou à conclusão de que já se imaginava sobre a interferência das emoções no aprendizado: emoções dos alunos influenciam na aprendizagem. Uma emoção autorregulada e motivada traz benefícios no academicismo (FRIESE, 2017).

$\mathrm{Na}$ aprendizagem autorregulada o aluno é protagonista. Nesta perspectiva a função do professor é dar suporte para que o aluno construa ativamente e que use de estratégias inovadoras e metacognitivas para traçar, alcançar e avaliar os objetivos (MEGA, 2014; AZEVEDO, 2010).

Baumeister (2018) nos apresentou a ideia de que o autocontrole é como um músculo; exige esforço, pode ser exercitado, se cansa, se desgasta e pode ser treinado (FRIESE, 2017). Esse treino exige uma alta capacidade de envolvimento porque a todo momento há uma luta intensa com nosso cérebro reptiliano. Para esclarecimento, Mograbi (2015) utilizando da teoria de MacLean, diz que o cérebro é dividido em três camadas e, a primeira, camada foi denominada de "cérebro protoreptiliano (reptiliano), o eixo mais básico do sistema nervoso, composto de medula espinhal, tronco cerebral, cerebelo, diencéfalo e gânglios basais, responsáveis por comportamentos estereotipados geneticamente determinados e funções parassimpáticas (involuntárias)" (p. 228). Retomando Baumeister, a necessidade da intensidade do treino "muscular" do autocontrole se dá pela construção milenar do cérebro reptiliano. Vencer essa construção milenar requer muito esforço. Por essa causa cedemos à lei do menor esforço em muitas áreas, incluindo nelas a aprendizagem. Naturalmente não queremos exercitar domínios mentais. Finalmente, Baumeister diz que o autocontrole não é uma capacidade aprendida e continuada automaticamente (e.g., andar de bicicleta). É preciso exercitá-lo. 


\subsection{TÉCNICAS DE AVALIAÇÃO DE FE E RE}

Perassinoto (2011) nos conta da sua investigação de avaliação em alunos do Ensino Fundamental. Nesta investigação verificou a relação entre a aprendizagem e a regulação emocional. Na sequência, algumas estratégias avaliativas aplicadas nos alunos:

a) Escala de Avaliação das Estratégias de Aprendizagem para 0 Ensino Fundamental (EAVAP-EF): construída por Boruchovitch e Santos, em 2001 (BORUCHOVITCH et al., 2006), avalia o repertório de estratégias de aprendizagem e a frequência com que são utilizadas. Um exemplo: marcar os valores de 0 (para nunca), 1 (para às vezes) e 2 (para sempre) no questionário: "Quando você está assistindo a uma aula, costuma anotar o que o(a) professor(a) está falando, mesmo quando ele(a) não manda ou não escreve nada na lousa?"; "Quando você estuda, percebe se não está conseguindo aprender?" e "Você costuma ficar pensando em outra coisa quando o(a) professor(a) está dando explicações?". (SUEHIRO, 2008).

b) Escala de Avaliação da regulação emocional para Estudantes do Ensino Fundamental (ERE-EF): Desenvolvida por Cruvinel e Boruchovitch (2008) com o objetivo de detectar como os alunos administram suas emoções. A escala é subdividida em: tristeza, raiva, medo e alegria. Essa escala tem por finalidade identificar: a) as emoções, b) quais os motivos que as geram, c) as estratégias de como lidar com elas e, d) de que forma pode ser prejudicial para o indivíduo.

c) Teste AC (Teste de Atenção Controlada). Esse teste idealizado por Cambraia (2009) tem por objetivo fornecer informações sobre a atenção de determinada pessoa: ao selecionar um estímulo, no meio de muitos outros, qual a probabilidade da pessoa voltar a manter sua atenção no estímulo selecionado após ser instigada por outros estímulos diferentes.

RC: 92018

Disponível em: https://www.nucleodoconhecimento.com.br/educacao/regulacaoemocional 
d) Para contribuição do Controle Inibitório, em específico o autocontrole, pode-se aplicar algumas tarefas avaliativas como, por exemplo, vá/não vá (JONES et al. 2003) e dia-noite (DIAMOND et al., 2002).

Além das avaliações observacionais dos pais, professores e familiares alguma ferramentas são apresentadas por Garcia-Andres (2010) como instrumentos de avaliação da regulação emocional: (1) Procedimento de decepção: quando crianças recebem um presente indesejado; (2) Morosidade ao embrulhar um presente: à frente das crianças uma pessoa leva 60 segundos para embrulhar um presente de forma ruidosa e, posteriormente, convida as crianças a abrir seu presente; (3) Anúncio de iogurte: a criança é orientada a simular uma emoção agradável enquanto prova um iogurte com um sabor desagradável; (4) Histórias: uma história é iniciada e a criança precisa decidir a continuação da mesma produzindo uma situação em que possa se sentir melhor.

Bariola (2012) também propõe uma escala de avaliação com o objetivo de auxiliar alunos na aprendizagem. O que ele chamou de regulação da emoção dos pais, o Emotion Regulation Questionnaire (ERQ): uma medida de dez itens que avalia a cognição, por exemplo, "Quando quero sentir menos emoções negativas, mudo a maneira como estou pensando na situação"; "Guardo minhas emoções para mim". Uma versão do $E R Q$ foi feita para crianças e adolescentes (ERQ-CA). Algumas alterações foram feitas como, por exemplo, a diminuição do número de alternativas e a simplificação no conteúdo da questão. Os itens incluem, por exemplo, "eu controlo meus sentimentos sobre as coisas, mudando a maneira como penso sobre elas" e "Quando estou me sentindo feliz, tomo cuidado para não demonstrar".

Um dos testes que pode contribuir na avaliação neuropsicológica é o CogniFit (disponível gratuitamente online ${ }^{[3]}$ ). Essa avaliação ajuda a identificar habilidades relacionadas à Função Executiva, entre as quais o Planejamento.

RC: 92018

Disponível em: https://www.nucleodoconhecimento.com.br/educacao/regulacaoemocional 
Outro teste muito conhecido para avaliar o planejamento, a tomada de decisão, autocontrole, e gerenciamento de tempo (a área responsável: córtex frontal ventrolateral) é o teste TOL: Tower of London.

Para teste de concentração cognitiva, ver o VISMEM-PLAN. "O objetivo é ajudar a realizar uma seleção básica da capacidade de organização, estruturação, atenção e sistematização das atividades. A concentração é uma parte vital da memória e por esse motivo o teste proporciona estímulos visuais simples para ajudar o usuário" (COGNIFIT, 2019).

Um conhecido teste utilizado para medir estímulos e a capacidade do autocontrole de uma criança é o teste do marshmallow. Diz Baumeister (2018) que proporcionalmente, quando aumentamos nossa capacidade de concentração, melhoramos o autocontrole e a competência cognitiva. Mischel (2016) evidenciou que "quanto mais as crianças conseguiam esperar pelo prêmio, mais elas se destacaram na aptidão escolar e de funções cognitivas na adolescência" (p. 5, 27).

Um teste utilizado especificamente em adolescentes, Emotion Regulation Index for Children and Adolescents, ERICA. O ERICA, desenvolvido por MacDermott et al. (2010) permite avaliar a regulação emocional em crianças e adolescentes de 9 aos 16 anos. Nunes, em seu artigo de revisão, faz uso da versão portuguesa do ERICA elaborado por Reverendo (2011) que desenvolveu uma versão portuguesa do Emotion Regulation Index for Children and Adolescentes (ERICA), a partir de uma amostra de 268 adolescentes, de ambos os sexos, com idades compreendidas entre os 12 e os 15 anos.

\section{CONCLUSÃO}

Valores morais ou, marcas de um bom caráter ou, caracterizações exemplares sempre estiveram sob a responsabilidade dos pais dos alunos. Escola existe para ensinar como aprender. Escola envolve cognição. No entanto, o que se tem pesquisado e comentado é que tais ações deverão fazer parte integrante nos

RC: 92018

Disponível em: https://www.nucleodoconhecimento.com.br/educacao/regulacaoemocional 
currículos das escolas do Estado Brasileiro. Diretrizes da BNCC que deverão ser implementadas a partir do ano de 2020. O foco não será somente a cognição, mas, também habilidades socioemocionais que incluem autoconhecimento, tomada de decisões responsáveis, autogerenciamento e consciência social ou cidadã. Tais conteúdos devem ser ensinados propositalmente aos alunos (não somente em ocasiões pontuais) e a escola deve oferecer espaço para que os alunos tenham oportunidade de colocá-los em prática.

Contudo, essa responsabilidade compartilhada não exime os pais das suas funções diretas na construção do equilíbrio emocional dos filhos. Reverendo (2015), utilizando do trabalho de pesquisa ERICA, chegou à conclusão de que a área socioemocional dos alunos está intimamente ligada com a aceitação ou rejeição parental. Pai carinhosos, atentos, disponíveis, que acompanham de perto o desenvolvimento dos filhos, contribuem positivamente na formação cognitiva e socioemocional dos mesmos.

Algumas habilidades emocionais que não estão dentro do quadro cognitivo entraram no foco do Ministério da Educação: administrar emoções pode influenciar ou contribuir para uma melhor absorção de conteúdo e desenvolvimento de um pensamento autônomo. Se espera através disso que os adolescentes sejam capazes de aprender a agir com maior responsabilidade, atuar funcionalmente em grupo, saber acatar as regras do convívio social, capaz de construir novas relações e ter respeito às diferenças. Crescer com a consciência de quem se é e, quem é o outro; reconhecer seus pontos fortes e fracos, pode contribuir para uma sociedade mais justa e pró-social (CASEL, 2015).

O MEC espera que com essas diretrizes as competências socioemocionais sejam direcionadas. Veja-se, como exemplo, os primeiros enunciados da Lei de Diretrizes de Base (LDB) que apontam a educação como um sistema abrangente que envolve a família, o convívio e movimentos sociais, as várias organizações civis e todas as manifestações culturais. Assevera a LDB que é de responsabilidade do Estado e da

RC: 92018

Disponível em: https://www.nucleodoconhecimento.com.br/educacao/regulacaoemocional 
família o pleno desenvolvimento do aluno e, na sequência, passa a enumerar os princípios que regem esse ensino: liberdade, pluralismo de ideias, respeito ao outro, garantia de padrão de qualidade, entre outros (LDB, 2017).

A relevância desse estudo é notada na aproximação de alguns campos das competências socioemocionais com áreas da neurociência. Vejamos algumas:

- Autoconhecimento (autopercepção): a capacidade de conhecer a si mesmo (incluindo as próprias emoções) e aplicar esse conhecimento nas ações diárias.

- Autocontrole, o que nesse trabalho foi chamado de autorregulação: controle dos impulsos, gerenciamento do estresse, planejar e definir metas.

- Tomada de decisão: a capacidade de tomar decisões com padrões éticos, construtivos, altruístas e que respeitem as normas sociais.

Retomando um pouco na história, Henri Wallon, filósofo, psicólogo, neuropsiquiatra, professor e político francês propôs, quando diretor da comissão eleita para restabelecer a educação na França pós-guerra (1945 a 1947), um processo de ensino-aprendizagem que passaria necessariamente pelo professor e aluno ao mesmo tempo levando em consideração o imbricamento entre educação e afetividade. Essa reforma contou com quatro princípios: (1) Justiça: qualquer criança ou jovem, independente de origem familiar, étnica, social e econômica tem igual direito ao total desenvolvimento. Que a única limitação sejam as próprias aptidões dos jovens; (2) Dignidade igual de todas as ocupações: não importa se o trabalho é manual ou intelectual. Tanto um quanto o outro será valorizado. A educação deverá dar suporte a um e a outro. (3) Orientação: todos os alunos terão direito a orientações em suas aptidões escolares e profissional; (4) Cultura geral: a especialização profissional não desobriga os alunos da cultura geral. Essa se faz necessária para a criação de uma mentalidade democrática e cidadã (MAHONEY, 2005).

RC: 92018

Disponível em: https://www.nucleodoconhecimento.com.br/educacao/regulacaoemocional 
Wallon dividiu a infância e adolescência em cinco estágios. O trabalho aqui se restringe ao $5^{\circ}$ estágio, da puberdade e adolescência (11 anos em diante). É nessa fase que o jovem começa a exploração de si mesmo (corporal, mental e espiritual), busca autonomia e busca apoio nos pares (mesmo período e mesmas construções). Wallon continua dizendo que nessa fase é comum a prática da oposição: instrumento de aprofundamento e de identificação de ideias, sentimentos e valores (MAHONEY, 2005, p. 23). Nessa perspectiva cognição e regulação emocional caminham lado a lado no processo ensino-aprendizagem.

Juntamente com esses dados educacionais e teorias que apontam para a necessidade do cuidado socioemocional, pesquisas neurocientíficas estruturam de forma técnica que não basta somente cuidar de uma parte do ser. Caso a habilidade socioemocional não seja acompanhada, estimulada e aperfeiçoada, mesmo que alguém tenha grande habilidade cognitiva e sem nenhum histórico de deficiência físico-biológica, poderá apresentar maus resultados académicos diante de estresse, insegurança e ansiedade.

\section{REFERÊNCIAS BIBLIOGRÁFICAS}

ALBUQUERQUE, Maria Luísa. Síndromes frontais: Avaliação do lobo frontal (LF) e suas conexões. Psicologia vol.16 no.1 Lisboa, 2002. Disponível em $<$ http://www.scielo.mec.pt/scielo.php?script=sci_arttext\&pid=S087420492002000100007>.

ALMEIDA, Rosa Maria Martins de; CABRAL, João Carlos Centurion; NARVAES, Rodrigo; Behavioural, hormonal and neurobiological mechanisms of aggressive behaviour in human and nonhuman primates. SienceDirect, 2015. Disponível em <https://www.sciencedirect.com/science/article/pii/S0031938415001316>.

ANDRETTA, Ilana; SILVA, J. Garcia da; SUSIN, Nathália \& FREIRE, Suzana Dias. Metacognição e Aprendizagem: como se relacionam. In Psico, v. 41, n. 1, pp. 713 2010.

Disponível em

RC: 92018

Disponível em: https://www.nucleodoconhecimento.com.br/educacao/regulacaoemocional 


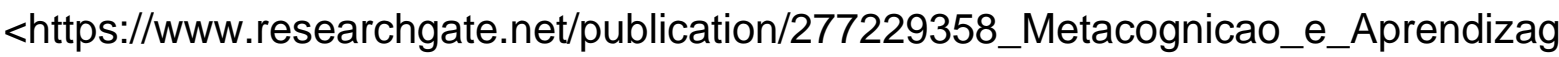
em_como_se_relacionam>.

AZEVEDO, R.; MOOS, D.C.; JOHNSON, A.M. \& CHAUNCEY, A.D. Medir processos reguladores cognitivos e metacognitivos durante aprendizagem hipermídia: questões e desafios. Psicólogo Educacional, 2010. Disponível em <https://www.tandfonline.com/doi/full/10.1080/00461520.2010.515934>.

BADDELEY, A.D. The episodic buffer: a new component of working memory? Trends in Cognitive Sciences, 4, 417-423. 2000. Disponível em <https://www.sciencedirect.com/science/article/abs/pii/S1364661300015382>.

BARIOLA, E., Hughes, E. K., \& Gullone, E. Relationships between parent and child emotion regulation: A brief report. Journal of Child and Family Studies, 21, 443-448. 2012. Disponível em <https://link.springer.com/article/10.1007\%2Fs10826011-9497-5>.

BASTOS, Lijamar de Souza \& ALVES, Marcelo Paraíso. As influências de Vygotsky e Luria à neurociência contemporânea e à compreensão do processo de aprendizagem. REVISTA PRÁXIS, no 10, 2013. Disponível em <http://revistas.unifoa.edu.br/index.php/praxis/article/viewFile/580/539>.

BAUMEISTER, Roy F., Self-regulation, ego depletion, and inhibition. SiencDirect, 2014.

Disponível em <https://www.sciencedirect.com/science/article/pii/S0028393214002759>

BAUMEISTER, Roy F.; DIANNE M. Tice, \& KATHLEEN D. Vohs. The strength model of self-regulation: Conclusions from the second decade of willpower research. Perspectives on Psychological Science, 2018. Disponível em $<$ https://journals.sagepub.com/doi/full/10.1177/1745691617716946>.

RC: 92018

Disponível em: https://www.nucleodoconhecimento.com.br/educacao/regulacaoemocional 
BENCZIK, Edyleine B.P.; LEAL, Graziella Ceregatti \& CARDOSO, Tábata. A utilização do teste de atenção concentrada (AC) para a população infantojuvenil: uma contribuição para a avaliação neuropsicológica. PEPSIC, 2016. Disponível em <http://pepsic.bvsalud.org/scielo.php?script=sci_arttext\&pid=S0103$84862016000100005>$.

BNCC. Base Nacional Comum Curricular. Governo Federal. Disponibilizado em $<$ http://basenacionalcomum.mec.gov.br/images/BNCC_EI_EF_110518_versaofinal_s ite.pdf>.

BNCC. Competências socioemocionais como fator de proteção à saúde mental e ao bullying. shttp://basenacionalcomum.mec.gov.br/implementacao/praticas/caderno-depraticas/aprofundamentos/195-competencias-socioemocionais-como-fator-deprotecao-a-saude-mental-e-ao-bullying.>.

CARLSON, S. M.; Davis, A. C. \& Leach, J. G., Less is more: Executive function and symbolic representation in preschool children. Psychological Science, 2005. Disponível em <https://www.ncbi.nlm.nih.gov/pubmed/16102063>.

CARLSON, Stephanie M. \& WANG, Tiffany S. Inhibitory control and emotion regulation in preschool children. Cognitive Development. 2007. Disponível em <https://www.sciencedirect.com/science/article/pii/S088520140700055X>.

CARDOSO, Caroline de Oliveira. Programas de intervenção neuropsicológica precoce-preventiva: estimulação das funções executivas em escolares, PUCRS, 2017. Disponível em <http://tede2.pucrs.br/tede2/handle/tede/7287>.

CASEL. Effective social and emotional learning programs: Middle and high school edition. Chicago, IL: Author. 2015. 
CHAN, R. C.; SHUM, D.; TOULOPOULOU, T. \& CHEN, E. Y., Assessment of executive functions: Review of instruments and identification of critical issues. Archives of clinical neuropsychology, 23(2), 2008. Disponível em <https://academic.oup.com/acn/article/23/2/201/3079>.

COGNIFIT. Revista Eletrônica. https://www.cognifit.com/br/habilidadecognitiva/planejamento>.

COGNIFIT. Teste de Concentração. <https://www.cognifit.com/br/cognitiveassessment/battery-of-tests/vismem-plan-test/concentration-test. >.

CRUM, James E. Controlling Your Emotions: The role of executive function in emotion regulation. Psycology Today, 2017. Disponível em $<$ https://www.psychologytoday.com/intl/blog/the-executive-brain/201710/controllingyour-emotions>.

CRUVINEL, Miriam \& BORUCHOVITCH, E. Regulação Emocional: A Construção de um Instrumento e Resultados Iniciais. Psicologia em Estudo, Maringá, v. 15, n. 3, p. 537-545, jul./set. $2010 . \quad$ Disponível em: <http://www.scielo.br/scielo.php?script=sci_arttext\&pid=S1413$73722010000300011>$.

DAHLITZ, Matthew. The Psychotherapist's Essential Guide to the Brain. The Science of Psychotherapy, 2017. Disponível em <https://www.thescienceofpsychotherapy.com/prefrontal-cortex/>.

DAMÁSIO, A. O erro de Descartes. Lisboa: Publicações Europa-América, 1994. DIAMOND, Adele. Executive Functions, in Annual Reviews. 2013. Diponível em <https://www.annualreviews.org/doi/full/10.1146/annurev-psych-113011-143750>.

RC: 92018

Disponível em: https://www.nucleodoconhecimento.com.br/educacao/regulacaoemocional 
DIAMOND, Adele. Activities and Programs That Improve Children's Executive Functions. 2012. Pesquisa realizada em 02/10/19. Disponível em <https://doi.org/10.1177/0963721412453722>.

DIAMOND, Kirkham NZ, Amso D. Conditions under which young children can hold two rules in mind and inhibit a prepotent response. In PubMed, 2002. Disponível em <https://www.ncbi.nlm.nih.gov/pubmed/12005379>.

DIAS, Natália Martins \& MECCA, Tatiana P. (Org.). Contribuições da Neuropsicologia e da Psicologia para Intervenção no Contexto Educacional. MEMNON: 2015,

EDUCAÇÃO, Revista. A história, os pilares e os objetivos da educação socioemocional. Revista Educação. Disponível em: $<$ http://www.revistaeducacao.com.br/historia-os-pilares-e-os-objetivos-da-educacaosocioemocional.

EDUCAÇÃOINFANTIL. Saiba aplicar competências socioemocionais na BNCC $\begin{array}{lllll}\text { para educação } & \text { infantil } & {[S I]} & \text { Disponível } & \text { em }\end{array}$ $<$ https://educacaoinfantil.aix.com.br/competencias-socioemocionais-para-educacaoinfantil/>.

EDUCADOR360. Habilidade Socioemocionais e BNCC: formação de professores. <https://educador360.com/gestao/habilidades-socioemocionais-bnccformacao-professores/.>.

EISENBERG, Nancy; SPINRAD, Tracy L., \& Natalie D. Eggum. Emotion-Related Self-Regulation and Its Relation to Children's Maladjustment. Annual Review of Clinical Psychology, $2010 . \quad$ Disponível em <https://doi.org/10.1146/annurev.clinpsy.121208.131208>.

RC: 92018

Disponível em: https://www.nucleodoconhecimento.com.br/educacao/regulacaoemocional 
ESPECIAL. Competências socioemocionais ${ }_{1}$ Revista Porvir, da Série Diálogos - O Futuro se Aprende, 2014.<http://porvir.org/especiais/socioemocionais/>.

ETTENHOFER ML; HAMBRICK DZ \& ABELES N. Reliability and stability of executive functioning in older adults. In PubMed, Neuropsychology. 2006. Disponível em <https://www.ncbi.nlm.nih.gov/pubmed/16938023>.

EVANS, Daniel R., Ian A. Boggero, and Suzanne C. Segerstrom. The nature of selfregulatory fatigue and "ego depletion: lessons from physical fatigue. Personality and Social Psychology Review, 2016. <https://journals.sagepub.com/doi/full/10.1177/1088868315597841>.

FONSECA, Luisa Mocelin. Compreensão leitora e atenção seletiva: um estudo com alunos do ensino médio. PUCRS, 2013. Disponível em <http://tede2.pucrs.br/tede2/handle/tede/2084>.

FREIRE, Luiz Gustavo Lima. Concepções e autorregulação da aprendizagem da arte. Revista Quadrimestral da Associação Brasileira de Psicologia Escolar e Educacional, SP. Volume 18, Número 3, Setembro/Dezembro de 2014. Disponível em: <http://www.scielo.br/pdf/pee/v18n3/1413-8557-pee-18-03-0391.pdf>.

FRIEDMAN, N. P.; HABERSTICK, B. C.; WILLCUTT, E. G.; MIYAKE, A.; YOUNG, S. E.; CORLEY, R. P. \& Hewitt, J. K. Greater attention problems during childhood predict poorer executive functioning in late adolescence. Psychological science, 18(10), 2007. Disponível em $<$ https://scholar.google.com.br/scholar?q=Friedman,+Haberstick,+Willcutt,+Miyake,+ Young+et+al.+(2007\&hl=en\&as_sdt=0\&as_vis=1\&oi=scholart\#d=gs_cit\&u=\%2Fschol ar\%3Fq\%3Dinfo\%3A2AVNsN5xTE0J\%3Ascholar.google.com\%2F\%26output\%3Dcit e\%26scirp\%3D0\%26hl\%3Den>.

RC: 92018

Disponível em: https://www.nucleodoconhecimento.com.br/educacao/regulacaoemocional 
FRIESE, M., Frankenbach, J., Job, V., \& Loschelder, D. D. Does self-control training improve self-control? A meta-analysis. Perspectives on Psychological Science, 2017._https://journals.sagepub.com/doi/full/10.1177/1745691617697076>.

FUSTER, Damaris (Et al.) The Relation between Executive Functioning and Emotion Regulation in Young Children. [SI] disponível em $<$ https://pdfs.semanticscholar.org/c17b/b1a731bcc4236bd6836ae17cf80eaf2389bd.p df>.

FUSTER, J. The Prefrontal Córtex.Time is of the essence. Neuron, 30, 319-333, 2001.

GARCIA-ANDRES, Esther; HUERTAS-MARTÍNEZ, J.A.; ARDURA, A. \& FERNÁNDEZ-ALCARAZ, Camino. Emotional Regulation and Executive Function Profiles of Functioning Related to the Social Development of Children. In Sciencedirect, 2010.2 Disponível em <https://www.sciencedirect.com/science/article/pii/S1877042810017908>.

GIANNESI, Iraceles de Lourdes; MORETTI, Lucia H. Contribuições da Neuropsicologia nas Dificuldades de Aprendizagem Escolar. Psicologia, PT, 2015. Disponível em $<$ https://www.psicologia.pt/artigos/ver_artigo.php?codigo=A0866>.

GILBERT, K. (2012). The neglected role of positive emotion in adolescent psychopathology. Clinical Psychology Review, 2012. Disponível em <https://www.sciencedirect.com/science/article/pii/S0272735812000694>.

GOLDSTEIN, Sam; NAGLIERI, Jack A.; PRINCIOTTA, Dana \& OTERO, Tulio M. Uma revisão das definições de funções executivas. Capítulo 1, in Comunidade Aprender Criança, 2013. Disponível em $<$ https://www.aprendercrianca.com.br/noticias-do-cerebro/edicao-36-agosto-de2014/388-uma-revisao-das-definicoes-de-funções-executivas>.

RC: 92018

Disponível em: https://www.nucleodoconhecimento.com.br/educacao/regulacaoemocional 
GOMES, C. M. A., \& BORGES, O. Qualidades psicométricas do conjunto de testes de inteligência fluida. Avaliação psicológica, 8(1), 2009. Disponível em $<$ https://www.redalyc.org/pdf/3350/335027279003.pdf>.

GUERRA, C. G.; CANDEIAS, A.; \& PRIETO, G. Flexibilidade Cognitiva: Repensar - Conceito e a Medida da Inteligência. Cognição, Aprendizagem e Rendimento-I Seminário Internacional, $2014 . \quad$ Disponível em $<$ https://core.ac.uk/download/pdf/55628831.pdf\#page=6>.

HARVARD UNIVERSITY. Young Children Develop in an Environment of Relationships. [SI] The National Scientific Council on the Developing Child, housed at the Center on the Developing Child. Disponível em $<$ https://developingchild.harvard.edu/wp-content/uploads/2004/04/Young-ChildrenDevelop-in-an-Environment-of-Relationships.pdf>.

HOFMANN, Wilhelm; ALLAN. Executive functions and self-regulation, in SienceDirect, Volume 16, Issue 3, March 2012, Pages 174-180. Disponível em <https://www.sciencedirect.com/science/article/pii/S1364661312000289>.

HUME, David. Coleção os Pensadores. São Paulo: Editora Nova Cultural, 1999.

JONES, Laura B.; ROTHBART, Mary K.\& POSNER, Michael I. Development of executive attention in preschool children. Wliley Oneline Library, 2003. Disponível em <https://doi.org/10.1111/1467-7687.00307>.

JOU, Graciela Inchausti de, \& SPERB, Tania Mar. A metacognição como estratégia reguladora da aprendizagem. Psicol. Reflex. Crit. [online]. 2006. Disponível em <http://www.scielo.br/scielo.php?script=sci_abstract\&pid=S0102$79722006000200003 \& \operatorname{lng}=e n \& n r m=i s o \& t \operatorname{lng}=p t>$.

LDB. Lei de diretrizes e bases da educação nacional. Brasília: Senado Federal, Coordenação de Edições Técnicas, 2017. Disponível em 
$<$ https://www2.senado.leg.br/bdsf/bitstream/handle/id/529732/lei_de_diretrizes_e_ba ses_1ed.pdf>.

LECHNER, Clemens M.;

\&

TOMARISK,

Martin J.

Preparing for uncertain careers: How youth deal with growing occupational un certainties before the education-to-work transition. SienceDirect, 2016. Disponível em <https://doi.org/10.1016/j.jvb.2016.08.002>.

LEAHY, Robert L.; TIRCH, Dennis \& NAPOLITANO, L.A. Regulação Emocional em Psicoterapia: Um Guia para o Terapeuta Cognitivo. Porto Alegre: Artmed, 2013.

LIMA, Ana G.B. de Sousa; MARQUES, Fernanda H.C. \& CARVALHO, R.B. Projeto vida: educação científica para estudantes do ensino fundamental anos iniciais. Brazil J. of Development, v. 5, n. 9, p. 16025-16035, 2019. Disponível em <http://www.brazilianjournals.com/index.php/BRJD/article/view/3375/3219>.

LINHARES, Maria B.M. \& MARTINS, Carolina B.S. O processo da autorregulação no desenvolvimento de crianças. Scielo, Estud. psicol. (Campinas) vol.32 no.2 $\begin{array}{llll}\text { Campinas } & \text { April/June } & 2015 . & \text { Disponível em }\end{array}$ $<$ http://www.scielo.br/scielo.php?script=sci_arttext\&pid=S0103166X2015000200281\#B17>.

LUCCA, Silvana Aparecida de; MANCINE, Márcia S., \& DELL'AGLI, Betânia A.V. Dificuldade de aprendizagem: contribuições da avaliação neuropsicológica. Pensamento Plural: Revista Científica, São João da Boa Vista, v.2, n.1, 2008. Disponível em <http://www.fae.br/2009/PensamentoPlural/Vol_2_n_1_2008/artigo_dificuldadedeapr endizagem_contribuicoes.pdf>.

MACDERMOTT, S. T.; GULLONE, E.; ALLEN, J. S.; KING, N. J.; \& TONG, B. The Emotion regulation index for children and adolescents (ERICA): $A$ 
Psychometric investigation. Journal of Psychology and Behavioral Assessment, 2010.

MAHONEY, A. Alvarenga e ALMEIDA, Laurinda R. de. Afetividade e processo ensino-aprendizagem: contribuições de Henri Wallon. Psicologia da educação [online]. 2005, n.20, pp. 11-30. Disponível em <http://pepsic.bvsalud.org/scielo.php?script=sci_arttext\&pid=S1414$69752005000100002>$.

MCCLELLAND, Megan M.; GELDHOF, G.J.; CAMERON, C.E.; WANLESS, S.B. Development and Self-Regulation. In Wiley Online Library, 2015. Disponível em $<$ https://doi.org/10.1002/9781118963418.childpsy114>.

MEDINEWS. <http://medinews.com.br/pesquisa-mostra-que-cerebro-incita-serhumano-a-lei-do-menor-esforcos.

MEGA, C.; RONCONI, L., \& DE BENI, R. What makes a good student? How emotions, self-regulated learning, and motivation contribute to academic achievement. Journal of educational psychology, 2014. Disponível em $<$ https://www.researchgate.net/publication/263916847_What_Makes_a_Good_Stude nt_How_Emotions_Self-

Regulated_Learning_and_Motivation_Contribute_to_Academic_Achievement>.

MELTZER, Lynn. Promoting Executive Function in the Classaroom. New York: Guilford Press, 2010.

MELTZER, Lynn. Executive Function in Education. Second Edition: From Theory to Practice, editado por Lynn Meltzer. 2013.

MISCHEL, Walter. O teste do marshmallow: Porque a força de vontade é a chave do sucesso. Objetiva, 2016. Disponível em <https://books.google.com.br/books?hl=en\&lr=\&id=wudHDAAAQBAJ\&oi=fnd\&pg=PT 
$4 \& d q=O+$ teste + do + marshmallow $+\& o t s=p 5 p Z f v A a t W \&$ sig $=4 F R-$

4xpN4fn0B5Dd4UGMZW1Rswo\&redir_esc=y\#v=onepage\&q=0\%20teste\%20do\%20 marshmallow\&f=false $>$.

MOGRABI, Gabriel José Corrêa. Considerações sobre a teoria do cérebro triuno e sua relevância para uma filosofia da mente e das emoções. Veritas (Porto Alegre), $2015 . \quad$ Disponível em <http://revistaseletronicas.pucrs.br/ojs/index.php/veritas/article/view/21861/13729>.

MORRISON, F. J.; PONITZ, C. C., \& MCCLELLAND, M. M. Self-regulation and academic achievement in the transition to school. In S. D. Calkins \& M. A. Bell (Eds.), Human brain development. Child development at the intersection of emotion and cognition (pp. 203-224), 2010.

NUNES, Ana M.N.M. Salvador. Regulação Emocional, Experiência, Expressão e Controlo da Raiva em Adolescentes. ISPA - Instituto Universitário Ciências Psicológicas, sociais e da via, 2013. Disponível em $<$ http://repositorio.ispa.pt/bitstream/10400.12/2763/1/15271.pdf>.

PENIDO, Anna. Nova Escola, Bncc e suas Competências: Qual aluno queremos formar? [SI]. Pesquisa realizada em agosto de 2019. Disponível em: $<$ https://novaescola.org.br/bncc/conteudo/2/bncc-e-suas-competencias-qual-alunoqueremos-formar>.

PERASSINOTO, M. G. M. Estratégias de Aprendizagem no Ensino Fundamental: Relações com Regulação Emocional, Motivação e Rendimento Escolar. (Dissertação de Mestrado). Universidade Estadual de Campinas, Campinas- $\quad$ SP, $2011 . \quad$ Disponível em <http://repositorio.unicamp.br/bitstream/REPOSIP/250788/1/Perassinoto_MariaGislai neMarques_M.pdf>.

RC: 92018

Disponível em: https://www.nucleodoconhecimento.com.br/educacao/regulacaoemocional 
PRIMI, Ricardo. Inteligência fluida: definição fatorial, cognitiva e neuropsicológica. Paidéia, Ribeirão Preto, 2002. Disponível em $<$ http://www.scielo.br/scielo.php?script=sci_arttext\&pid=S0103863X2002000200005\#targetText=A\%20tend\%C3\%AAncia\%20corrente\%20\%C3\%A 9\%20associar,de\%20rotas\%20ou\%20flexibilidade\%20adaptativa.>.

REIS, H.M.; KASSA, R.Jum Ono; JAQUES, Patricia; ISOTANI, Seiji; \& FILHO, Ramílio, Regulação emocional em ambientes educacionais: um mapeamento sistemático. USP, São Carlos - SP, 2018. Disponível em: <https://www.brie.org/pub/index.php/sbie/article/view/8050/5741>.

REVERENDO, M. I. Regulação emocional, satisfação com a vida \& perceção da aceitação - rejeição parental. Estudo de adaptação e validação da versão portuguesa do Emotion Regulation Index for Children and Adolescentes (ERICA). Faculdade de Psicologia e Ciências da Educação. Universidade de Coimbra, 2011. Disponível em <https://estudogeral.sib.uc.pt/handle/10316/18199>

RIBEIRO, Célia. Metacognição: Um Apoio ao Processo de Aprendizagem. Scielo, Psicologia: Reflexão e Crítica, 2003, 16(1), pp. 109-116. Disponível em <http://www.scielo.br/pdf/\%0D/prc/v16n1/16802.pdf>.

ROCHA, Ana Maria; CANDEIAS, Adelinda Araújo, \& SILVA, ADELINA Lopes da. Regulação das emoções na infância: Delimitação e definição. Psychologica 611. 2018.

$<\mathrm{https}: / /$ books.google.com.br/books?hl=en\&lr=\&id=BEVPDwAAQBAJ\&oi=fnd\&pg=P A7\&dq=Regula\%C3\%A7\%C3\%A30+emocional+defini\%C3\%A7\%C3\%A3o\&ots=bSfVxbam-

\&sig=zxDaOKXD7rtYnkBm0xlidVNFI4U\#v=onepage \&q=Regula\%C3\%A7\%C3\%A3o $\% 20$ emocional\%20defini\%C3\%A7\%C3\%A3o\&f=false>.

ROSA, Cleci T. Werner da; SANTOS, Ana Cláudia dos; \& RIBEIRO, Cássia. Pensamento Metacognitivo em Estudantes do Ensino Médio: Elaboração, 
Validação e Aplicação de um Instrumento. In IV CIECITEC (Congresso Internacional de Educação Científica e Tecnologia), 2017. Disponível em $<$ http://www.santoangelo.uri.br/anais/ciecitec/2017/resumos/comunicacao/trabalho_2 742.pdf>.

SERUCA, Tânia C. Mira. Córtex Pré-frontal, funções executivas e Comportamento Criminal. ISPA - Instituto Universitário no ano de 2013. Disponível em <http://repositorio.ispa.pt/bitstream/10400.12/2735/1/TES\%20SERU1.pdf>.

SILVA, Eliana \& FREIRE, Tereza. Regulação emocional em adolescentes e seus pais: Da psicopatologia ao funcionamento ótimo. Scielo Portugal. Aná. Psicológica vol.32 no.2 Lisboa jun. 2014. Disponível em $<$ http://www.scielo.mec.pt/scielo.php?script=sci_arttext\&pid=S0870$82312014000200005>$.

SUEHIRO, A.C.B.; BORUCHOVITCH E. \& SCHELINI P.W. Estratégias de aprendizagem e a regulação da emoção no Ensino Fundamental. PEPSIC, 2018. Disponível em <http://pepsic.bvsalud.org/pdf/eip/v9n3s1/a07.pdf>.

SUVEG, C.; SOUTHAM-GEROW, M.; GOODMAN, K. L., \& Kendall, P. C. The role of theory and research in child therapy development. Clinical Psychology: Science and Practice, 14(4), 2007. Disponível em $<$ https://onlinelibrary.wiley.com/doi/full/10.1111/j.1468-2850.2007.00096.x>.

YANG, Y.; RAINE, A.; LENCZ, T.; BIHRLE, S.; LACASSE, L., \& Colletti, P. Volume reduction in prefrontal gray matter in unsuccessful criminal psychopaths. Biological psychiatry 57, no. 10, 2005. Disponível em <https://www.sciencedirect.com/science/article/pii/S0006322305000983?via\%3Dihub $>$.

RC: 92018

Disponível em: https://www.nucleodoconhecimento.com.br/educacao/regulacaoemocional 


\section{APÊNDICE - REFERÊNCIA DE NOTA DE RODAPÉ}

2. Rocha (2018) nos apresenta inúmeros aspectos das emoções, como, por exemplo regulação do afeto, do humor, o coping e os mecanismos de defesa. Também nos apresenta vários entrelaçamentos, como por exemplo, regulação externa e autorregulação ou; regulação da intenção emocional versus regulação automática da emoção. Nenhum desses detalhes iremos abordar neste trabalho.

3. https://www.cognifit.com/aplicaciones/html5/index/assessment/ASSESSMENT_AmP Or

Enviado: Maio, 2021.

Aprovado: Julho, 2021.

RC: 92018

Disponível em: https://www.nucleodoconhecimento.com.br/educacao/regulacaoemocional 